\title{
睡眠と脂質代謝との関連
}

\section{Relationship between Sleep and Lipid Metabolism}

\section{宮田 聖子}

名古屋大学大学院医学系研究科

精神医療学寄附講座

干 466-8550

愛知県名古屋市昭和区鶴舞町 65

Seiko MIYATA

Department of Clinical Psychiatry, Nagoya University Graduate School of Medicine

65 Tsurumai-cho Showa-ku, Nagoya, Aichi, 466-8550, Japan

\section{岩本 邦弘}

名古屋大学大学院医学系研究科

発達・老年精神医学分野

T 466-8550

愛知県名古屋市昭和区鶴舞町 65

Kunihiro IWAMOTO

Department of Developmental and Geriatric Psychiatry,

Nagoya University Graduate School of Medicine

65 Tsurumai-cho Showa-ku, Nagoya, Aichi, 466-8550, Japan

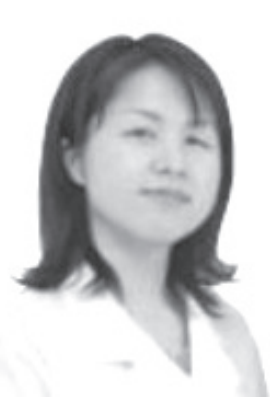

\author{
野田 明子 \\ 中部大学大学院生命健康科学研究科 \\ 生命医科学専攻 \\ T 467-8501 \\ 愛知県春日井市松本町 1200
}

Akiko NODA
Department of Biomedical Sciences,
Chubu University Graduate School of
Life and Health Sciences
1200 Matsumoto-cho, Kasugai, Aichi,
487-8501, Japan
尾崎 紀夫
名古屋大学大学院医学系研究科
精神医学・親と子どもの心療学分野
† 466-8550
愛知県名古屋市昭和区鶴舞町 65
Norio OZAKI
Department of Psychiatry,
Nagoya University Graduate School
of Medicine
65 Tsurumai-cho Showa-ku, Nagoya,
Aichi, 466-8550, Japan

論文要旨：睡眠は，代謝調節に重要な役割を果たし，睡眠障害は脂質代謝異常を来す。中でも睡眠呼吸障 害は，脂質代謝異常，高血圧や糖尿病と密接に関わっており，心血管病の発症リスクを高めるとの証左が多 い。近年, 質量分析計を用い睡眠障害による脂質代謝異常の分子的なメカニズムを解明しようという試みが なされている。閉塞性睡眠時無呼吸患者において重症度と脂質分子種プロファイルが関連すること, 睡眠時 間制限によりいくつかの脂質分子種が変動することが報告されている。質量分析計を用いた脂質代謝産物の 包括的解析は, 睡眠/覚醒調節および関連する代謝プロセスの理解をさらに深め, 代謝プロファイリングを 利用することで病態および治療効果評価においてバイオマーカー探索に不可欠となると考えられている。本 稿では，睡眠と脂質代謝異常との関連について疫学研究および質量分析による研究を紹介する。

Abstract: Sleep plays an important role in metabolic regulation and insomnia disorder, short sleep and long sleep are also related with dyslipidemia. Among them especially, numerous evidence suggests that sleep disordered breathing is closely associated with dyslipidemia, hypertension and diabetes, and increases the risk of cardiovascular disease. In addition, in recent years, studies that elucidate the molecular mechanism of dyslipidemia due to sleep disorder by a mass spectrometer is increasing. The relationship between severity and lipid species profile in patients with obstructive sleep apnea has been reported, and the previous study revealed a significant overall shift in lipid metabolism, with higher levels of phospholipids under sleep-restricted conditions. Comprehensive analysis of lipid metabolites using a mass spectrometry further the understanding of sleep/wake regulation and the associated metabolic processes, and will be vital to identify robust biomarkers for disease states and drug efficacy. In this paper, we review epidemiological and mass spectrometric studies on the relationship between sleep and dyslipidemia.

Key words: sleep duration, obstructive sleep apnea, lipidomics, dyslipidemia 


\section{1 はじめに}

睡眠時間の短縮とその質の低下による健康への影響が 注目されるに従い，睡眠と健康への影響についての研究 報告は近年ますます増加している（Fig. 1)。我々が, 地 域在住高齢者を対象に不眠や短時間睡眠の動脈硬化への 影響を検討した結果，不眠があり睡眠時間が 5 時間以下 である高齢者では, 頸動脈の内中膜厚が増大し, プラー ク数が増加することを明らかにした ${ }^{1)}$ 。短時間および長 時間睡眠の両者が, 死亡率や糖尿病, 心血管病の発症率 の増加をもたらす ${ }^{2-4)}$ 。同様に，自覚的な睡眠の質の低 下も死亡率や心血管病の発症率の増加に関与している ${ }^{4)}$ 。 睡眠時間が， 7 時間より短く（短時間睡眠）なったり, 8 時間より長く（長時間睡眠）なったりすると， 7〜8 時 間睡眠に比し，心血管病の危険因子である高血圧やメ夕 ボリックシンドロームの有病率が高くなり, 睡眠時間と 有病率の関係はU 字型を示す ${ }^{5,6)}$ 。さらに, 睡眠の質の 低下が，高血圧および糖尿病のリスクを高める ${ }^{2,7)}$ 。

血中脂質の働きは, エネルギー貯蔵, シグナル伝達お よび生物膜構造において中心的な機能を有しており, そ れらの構造的および生化学的特徵が非常に多彩であるた め, 様々な細胞プロセスにおいて重要な役割を果たして いる。リピドミクスは, 生体脂質分子の大規模なプロファ イリングおよび定量化により, 分析化学および統計解析 に基づくパスウェイの包括的な研究および生理学的意義 の解釈をするための方法の一つである。リピドミクスに よる, 脂質分子の生理学的機能の探索だけでなく, 疾患
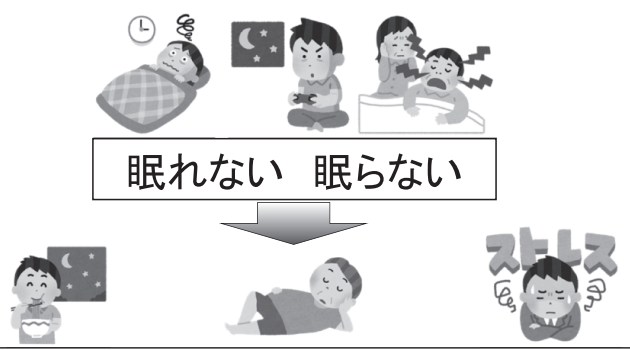

食事量増加 活動度低下 ストレス反応増加

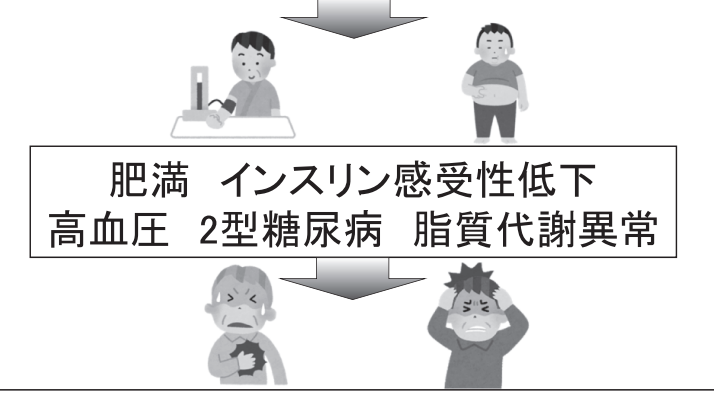

不整脈 動脈硬化 冠動脈疾患 脳卒中

Fig. 1 身体への影響 : 疫学研究·実験的研究のまとめ
の診断や治療のためのバイオマーカー探索も期待されて いる ${ }^{8)}$ 。本稿では, 質量分析計による脂質分子種解析の 概要および睡眠とリピドミクスとの関連の研究報告につ いてレビューする。

\section{2 睡眠障害と脂質代謝異常}

血中脂質, 総コレステロールおよびLDL コレステロー ルの増加は心血管病の確立された危険因子である。血中 脂質は, 食事, 喫煙や活動量などの生活習慣の影響を受 けるとされ，睡眠習慣との関連も近年報告が相次いでい る。閉塞性睡眠時無呼吸と血中脂質プロファイルにおけ る，18,116 例の患者を含む 64 の観察研究を用いたメ夕 アナリシスにより，閉塞性睡眠時無呼吸は脂質代謝異常 のリスク上昇, 総コレステロール, LDL コレステロー ルおよび中性脂肪の増加や HDL コレステロールの低下 と関連があることが明らかになった。睡眠中の無呼吸低 呼吸による慢性的な間歇的低酸素血症は, stearoylcoenzyme A desaturase-1 や活性酸素種を産生させた り, 脂質の過酸化や交感神経活動の活性化を引き起こす ことにより, 脂質代謝異常に関係している可能性が示さ れている ${ }^{9)}$ 。

一方，睡眠時間や睡眠の質との関連については，短時 間睡眠では脂質代謝異常（総コレステロールや中性脂肪 の増加）のリスクが上昇することが報告されている ${ }^{10,11) 。 ~}$ 4〜19 歳の幼児 - 青少年を $7 \sim 8$ 年追跡し， 睡眠時間と 脂質代謝異常との関連を検討した研究では, 睡眠時間が 1 時間延びる毎に高コレステロール血症のリスクが減少 することが確認された ${ }^{10)}$ 。40〜70 歳の成人 2579 例にお いて, 平均 2.6 年間追跡した研究により，6〜 7.9 時間の 睡眠に比し， 6 時間未満の睡眠では，HDL コレステロー ルの低下，中性脂肪の上昇が認められた ${ }^{11)}$ 。睡眠時間 の短縮は, 食欲および飽和脂肪酸を含む食品摂取の増大, 日常的な運動習慣の減少，ストレスとその影響によるカ テコラミン誘発性の脂肪分解の上昇により, 血中のコレ ステロールを増加させると考えられている。40６0 歳 の 6477 例において, 不眠障害と脂質代謝異常との関連 を調査した研究では， 5 年間の追跡期間のうちに, 不眠 障害患者の $15 \%$ が脂質代謝異常の治療を必要とし, そ のオッズ比は1.59（95\%信頼区間 1.19-2.12）であった ${ }^{12)}$ 。 しかし，16 例の一般住民におけるコホート研究を用い たメ夕解析では，短時間睡眠および長時間睡眠ともに， 脂質代謝異常の発症リスクとの関連は明らかにならな かった。その原因として，睡眠と脂質代謝異常に関する 報告は少なく，各研究により睡眠の影響は様々であるこ と, 睡眠時間のみに注目し, 脂質代謝異常との関連が指 摘されている他の睡眠障害の影響が考慮されていないこ 
とが挙げられている ${ }^{13)}$ 。これまでの実験的および疫学 研究により，短時間睡眠が脂質代謝へ影響を与えている ことは明らかであり, さらなる研究により睡眠時間と脂 質代謝異常との関係が明らかになることが期待されてい る。

\section{3 質量分析計による脂質の包括的解析}

リピドミクスとは, 細胞や生体内における多数の脂質 分子種の变動を網羅的に探索し，生命現象を包括的に理 解しようとする研究法の一つである。リピドミクス研究 においては, 疾患, 薬物や環境変化などによる脂質分子 種の含有量や組成における空間的および時間的な変化を 説明しうる膨大な情報が収集されてきている ${ }^{8)}$ 。夕ー ゲットおよびノンターゲットリピドミクスは，異なる特 徴を有する分析手法であり，これらのアプローチを組み 合わせることで, 複雑な生物学的マトリックスにおける 脂質分子種の同定・定量化を最大限に有効化できる。夕ー ゲットリピドミクスは, 測定対象を個別に限定し, 検出 感度を高める手法であり，プレカーサーイオンの特定の $\mathrm{m} / \mathrm{z}$ 值と特徵的なフラグメントイオンの $\mathrm{m} / \mathrm{z}$ 值を組み 合わせた選択的反応モニタリングと呼ばれる。ノンター ゲットリピドミクスは，1回の実施で出来るだけすべて の代謝産物について分析するという包括的な手法であ る。測定対象を非常に広くとることが出来る一方で, 重 要であるが測定限界を下回る微量な分子の存在を見逃す という久点もある。さらに, 両方法の中間として, 分子 の部分行動特性からフォーカスし, 代謝物をある程度限 定することにより，より微量な成分まで検出対象とする 手法もある (Fig. 2 $)^{14,15)}$ 。

\section{4 脂質メタボロームと概日リズム}

概日リズムシステムは, 脂質代謝を調整する上で重要 な役割を果たす。太陽周期と一致して, 概日リズムは, 脂質の吸収, 貯蔵, および輸送における毎日のリズムが 休息/活動および摂食周期と時間的に同調することを確 実にする ${ }^{16)}$ 。末梢組織では, 脂質生合成および脂肪酸 酸化に関与する何百もの遺伝子が, 時計タンパク質によ り周期的に活性化され, 抑制されているため, 脂質の概 日調節に直接的な機能を及ほしている。時計遺伝子機能 の異常は, 代謝表現型および脂質吸収に影響を与え, 概 日システムが正常なエネルギー代謝に必須であることが 証明されている。食事の組成と夕イミングは, 代謝経路 の日周調節に影響を与え, 夜食や過食といった食事行動 は脂質代謝の調節異常に関連している ${ }^{17)}$ 。メタボロミ クスおよびリピドミクスプラットフォームを用いた最近 の研究は, 脂肪酸, トリグリセライド, グリセロリン脂 質, ステロール脂質およびスフィンゴ脂質など何百もの 脂質種がヒトの血漿において概日調節されていることを 示した。10人の正常範囲内 BMI の健常男性において外 的刺激（睡眠／覚醒リズム, 食事, 運動）をコントロー ルし, 24 時間, 血中の脂質代謝産物をモニターした研 究では, 同定されたリン脂質のうち, リゾホスファチジ ルエタノールアミンは午後遅くおよび夕方にピークに達 し，続いてホスファチジルコリンが夕方にピークに達し た。対照的に, 検出された他の 2 つのホスホコリン (lysoPC (16:0) と lysoPC (18：1)) は，1日を通し て有意な変化を認めなかった ${ }^{18)}$ 。20人の健常男性にお いて, ターゲットリピドミクスアプローチにより, 263

\begin{tabular}{|c|c|c|}
\hline 分析手法 & 検出感度 & 測定対象 \\
\hline $\begin{array}{l}\text { 網羅的な手法 } \\
\text { Non-targeted method } \\
\text { サンプル中の分子を特 } \\
\text { 定の予見無しに解析 }\end{array}$ & $\begin{array}{c}\text { 同定感度低い } \\
\text { 量的に多い成分 }\end{array}$ & $\begin{array}{l}\text { 予期しない分子群を発 } \\
\text { 見する可能性 } \\
\text { (後から同定する必要が } \\
\text { ある) }\end{array}$ \\
\hline $\begin{array}{l}\text { フォーカスした手法 } \\
\text { Focused method } \\
\text { 特定の構造群に対象を } \\
\text { 絞り、その中での網羅 } \\
\text { 性を追求した解析 }\end{array}$ & 両方法の中間 & $\begin{array}{l}\text { 想定したカテゴリー内で } \\
\text { はあるが予期しない微 } \\
\text { 量成分の発見の可能性 } \\
\text { (想定したカテゴリー外 } \\
\text { の分子は検出できない) }\end{array}$ \\
\hline $\begin{array}{l}\text { 特定の分子解析の手法 } \\
\text { Targeted method } \\
\text { 特定の個別分子に対象 } \\
\text { を絞つた定量的解析 }\end{array}$ & $\begin{array}{l}\text { 同定感度高い } \\
\text { 微量成分の解析 }\end{array}$ & $\begin{array}{l}\text { 基本的には想定してい } \\
\text { る分子以外は検出でき } \\
\text { ない } \\
\text { 拡張により構造異性体 } \\
\text { の発見の可能性あり }\end{array}$ \\
\hline
\end{tabular}

Fig.2 リピドミクスにおける質量分析による解析手法（文献14より） 
の脂質分子種について 24 時間モニターした研究により, トリアシルグリセロールおよびジアシルグリセロールは 起床時間頃に最も高くなり, 一方, ホスファチジルコリ ンは午後から夕方にかけて最も高くなるという概日リズ ムが示された ${ }^{19)}$ 。脂質プロファイリングアプローチを 利用することで, 脂質代謝に関する食事内容 / タイミン グ，睡眠/覚醒リズムおよび概日リズムの相互作用，肥 満および代謝性疾患のリスクをよりよく理解することが 可能となる。

\section{5 睡眠呼吸障害と脂質メタボロームとの関連}

閉塞性睡眠時無呼吸が，心血管病の発症及び死亡率の 上昇に関与していることはよく知られており ${ }^{20)}$, 閉塞 性睡眠時無呼吸による代謝機能障害が心血管病の発症に 関与していることも報告されている ${ }^{21)}$ 。閉塞性睡眠時 無呼吸患者における心血管病リスクの早期発見やリスク 上昇に関与する病態の理解のためのバイオマーカー探索 が行われている。29例の正常耐糖能の閉塞性睡眠時無 呼吸患者と 21 例の対照群を比較した研究において, 脂 質メディエーターの一種であるアナンダミドは血圧と正 の相関を示した。アナンダミドは閉塞性睡眠時無呼吸患 者で非肥満対照群に比し高值であったが, アラキドン酸 濃度は両群間で有意差を示さず，高血圧と心血管病のリ スクが高い閉塞性睡眠時無呼吸患者の血圧調節における 内在性カンナビノイド系の関与が示唆された ${ }^{22)} 。 63$ 例 の肥満閉塞性睡眠時無呼吸患者の脂肪細胞中の脂肪酸と 睡眠との関連を検討した研究では，睡眠効率およびレム 睡眠量は, 飽和脂肪酸, 多価不飽和脂肪酸および n-3 脂 肪酸と正の相関を示した。さらに, n-3 脂肪酸は徐波睡 眠量とも有意な正の相関を示した。これら脂肪酸と睡眠 との関係は明らかにはなっていないが，ラットに飽和脂 肪酸，多価不飽和脂肪酸を多く含んだ食事を与えると， 睡眠の促進に重要な物質である内在性カンナビノイドの 細胞レベルに影響を与えること ${ }^{23)}, \mathrm{n}-3$ 脂肪酸がメラト ニンの前駆物質であるセロトニン産生に関与しているこ とから ${ }^{24)}$, 脂肪酸の睡眠制御に関わる物質の前駆体と しての機能との関連が推察されている ${ }^{25)}$ 。

近年, 閉塞性睡眠時無呼吸のさまざまな段階の代謝表 現型の研究にメタボロミクスが適用されている。睡眠ポ リグラフ検査後, 軽症から重症の閉塞性睡眠時無呼吸患 者から血漿サンプルを採取し, 高速液体クロマトグラフ - 四重極飛行時間型－質量分析計（LC-QTOF-MS）を 用いて血中脂質のプロファイルが実施された。重症（無 呼吸低呼吸指数 $\mathrm{AHI} \geq 30 / \mathrm{h}, \mathrm{n}=18$ ） と非重症（AHI $<30 / \mathrm{h}, \mathrm{n}=15 ）$ の閉塞性睡眠時無呼吸患者を判別可能 な 14 の代謝産物が同定された（グリセロリン脂質類,
ポルフィリン類, 脂肪酸類, アミノ酸類とその誘導体, ペプチド類）。血小板活性化因子およびリゾリン脂質は, 腸内細菌叢の活性に関連する化合物（胆汁色素およびピ ペコリン酸）とともに, 睡眠時無呼吸の代謝への影響の 理解に役立ち, 閉塞性睡眠時無呼吸のモニタリング有用 であると考えられている ${ }^{26)}$ 。AHI $\geq 15 / \mathrm{h}$ の閉塞性睡眠 時無呼吸の男性患者 36 例とコントロール 16 例の血中脂 質分子種をガスクロマトグラフィー質量分析 (GC/MS) により比較した研究では，6つの代謝産物および 22 の 脂質が同定され，閉塞性睡眠時無呼吸と強く関連した脂 質種は, グルタミン酸, デオキシ糖およびアラキドン酸, グリセロホスホエタノールアミン，スフィンゴミエリン およびリゾホスホコリンであった。これらの代謝産物お よび脂質種は, 炎症や糖代謝の経路と関わっており, 閉 塞性睡眠時無呼吸における心血管病リスクの早期検出 マーカーになりうる可能性が示された ${ }^{27)}$ 。しかし, こ れまでに実施された研究はいずれも小規模な集団であ り，閉塞性睡眠時無呼吸のバイオマーカーとして確立さ れるためには，大規模な独立した集団において再検証さ れる必要がある。

\section{6 睡眠不足・睡眠障害と脂質メタボロームとの関連}

12 人の健常成人において, 8 時間の通常睡眠の後, 24 時間断眠し，継続的に血中メタボロームの変動を観察し た研究では, 代謝産物の概日リズム（睡眠中に減少し, 覚醒中は増加する）および睡眠不足による概日リズム変 動の減弱が観察された。 8 時間の睡眠時と比較し, 24 時 間の断眠中, 3 種のリゾホスホリピド, 13 種のホスファ チジルコリンおよび 3 種のスフィンゴミエリンは，概日 リズムによる変動が減弱し，有意に増加したままであっ た ${ }^{28)} 。 10$ 人の健常成人において 2 日間の自然睡眠の後に, 連続した 5 日間の 4 時間睡眠および 12 時間のリカバリー ナイト時に, 血中の代謝産物を比較した研究では, 自然 睡眠時と 4 時間睡眠時との比較により，32 種の脂質お よび脂肪酸に有意な差が認められ，リカバリーナイトに よりいくつかの分子種は自然睡眠時と同じレベルに回復 したが, 回復しない分子種も認められた。この研究では, ラットにおいて同様な実験を実施し，5日間の睡眠制限 により，自然睡眠時と睡眠制限時で有意な変動の認めら れる 15 種の脂質が同定された。さらに，ジアシルグリ セロール 36:3 は, ヒトとラットの両方において, 睡眠 制限時に有意に減少し, リカバリーナイト時に自然睡眠 時のレベルまで回復した。リン脂質（ホスファチジルコ リン, リゾホスファチジルコリン， ホスファチジルエ夕 ノール，スフィンゴミエリン）もヒトとラットともに, 睡眠制限により有意に上昇していた ${ }^{29)}$ 。277 例のコホー 
卜研究参加者において，4週間の睡眠日誌の記録，採血 前日の睡眠時間と血中メタボロームとの関連の研究で は, 睡眠時間帯（就床時刻と起床時刻の中間時刻）の後 退は, 脂肪酸分子種を減少させる一方, 脂肪酸をミトコ ンドリア内へ輸送する役割を持っているアシルカルチニ ン分子種を増加させた。さらに，睡眠時間帯（就床時刻 と起床時刻の中間時刻）の後退は胆汁酸分子種の増加と も関連しており, 胆汁酸の増加は脂質代謝異常や血糖值 上昇との関連も報告されている ${ }^{30)}$ 。質量分析計を用い た脂質代謝産物の包括的解析は, 睡眠/覚醒調節および 関連する代謝プロセスの理解をさらに深め, 代謝プロ ファイリングを利用することで病態および治療効果評価 においてバイオマーカー探索に不可欠となると考えられ ている。

\section{7 おわりに}

質量分析計による脂質代謝の包括的解析により, 脂質 分子種の概日リズムや，睡眠呼吸障害や睡眠不足による 脂質プロファイルの変動などが報告されてきている。し かし、リピドミクスが比較的新しい研究分野であるため 研究報告数が少ないこと, 各研究における対象者数が少 ないことから，さらなる研究により睡眠と脂質代謝との 関連が明らかにされることが望まれる。リピドミクスは, 今後, 睡眠/覚醒リズム, 食事や運動など様々な要因が 関係している疾患において, 病態の理解, 早期診断・リ スク評価, 治療効果評価への貢献が期待できる。

\section{文 献}

1) Nakazaki, C.; Noda, A.; Koike, Y.; Yamada, S.; Murohara, T.; Ozaki, N. Am. J. Hypertens. 25, 1149-1155 (2012).

2) Cappuccio, F. P.; D’Elia, L.; Strazzullo, P.; Miller, M. A. Diabetes Care 33, 414-420 (2010).

3) Cappuccio, F. P.; Miller, M. A.; D’Elia, L.; Strazzullo, P. Sleep 33, 585-592 (2010).

4) Cooper, D.; Miller, M. A.; Cappuccio, F. P.; D’Elia, L.; Strazzullo, P. Eur. Heart J. 32, 1484-1492 (2011).

5) Gottlieb, D. J.; Redline, S.; Nieto, F. J.; Baldwin, C. M.; Newman, A. B.; Resnick, H. E.; Punjabi, N. M. Sleep 29, 1009-1014 (2006).

6) Buysse, D. J.; Jennings, J. R.; Hall, M. H.; Muldoon, M. F.; Flory, J. D.; Manuck, S. B. Sleep 31, 635-643 (2008).

7) Liu, R.-Q.; Qian, Z.; Trevathan, E.; Chang, J.-J.; Zelicoff, A.; Hao, Y.-T.; Lin, S.; Dong, G.-H. Hypertens. Res. 39, 54 (2015).

8) Hu, T.; Zhang, J.-L. J. Sep. Sci. 41, 351-372 (2018).

9) Adedayo, A. M.; Olafiranye, O.; Smith, D.; Hill, A.; Zizi, F.; Brown, C.; Jean-Louis, G. Sleep Breath. 18, 13-18 (2014).

10) Gangwisch, J. E.; Malaspina, D.; Opler, M. G.; Babiss, L.
A.; Turner, J. B.; Posner, K.; Shen, S.; Zammit, G. K.; Ginsberg, H. N. Sleep 33, 956-961 (2010).

11) Kim, J.-Y.; Yadav, D.; Ahn, S. V.; Koh, S.-B.; Park, J. T.; Yoon, J.; Yoo, B.-S.; Lee, S.-H. Sleep Med. 16, 1511-1515 (2015).

12) Haaramo, P.; Rahkonen, O.; Hublin, C.; Laatikainen, T.; Lahelma, E.; Lallukka, T. J. Sleep Res. 23, 283-291 (2014).

13) Kruisbrink, M.; Robertson, W.; Ji, C.; Miller, M. A.; Geleijnse, J. M.; Cappuccio, F. P. BMJ Open 7, e018585 (2017).

14）田口良. ファルマシア 48, 941-945（2012）.

15) Lee, H. C.; Yokomizo, T. Biochem. Biophys. Res. Commun. 504, 576-581 (2018).

16) Gooley, J. J.; Chua, E. C. J. Genet. Genomics 41, 231250 (2014)

17) Gooley, J. J. Proc. Nutr. Soc. 75, 440-450 (2016).

18) Ang, J. E.; Revell, V.; Mann, A.; Mantele, S.; Otway, D. T.; Johnston, J. D.; Thumser, A. E.; Skene, D. J.; Raynaud, F. Chronobiol. Int. 29, 868-881 (2012).

19) Chua, E. C.; Shui, G.; Lee, I. T.; Lau, P.; Tan, L. C.; Yeo, S. C.; Lam, B. D.; Bulchand, S.; Summers, S. A.; Puvanendran, K.; Rozen, S. G.; Wenk, M. R.; Gooley, J. J. Proc. Natl. Acad. Sci. USA 110, 14468-14473 (2013).

20) Javaheri, S.; Barbe, F.; Campos-Rodriguez, F.; Dempsey, J. A.; Khayat, R.; Javaheri, S.; Malhotra, A.; MartinezGarcia, M. A.; Mehra, R.; Pack, A. I.; Polotsky, V. Y.; Redline, S.; Somers, V. K. J. Am. Coll. Cardiol. 69, 841858 (2017).

21) Drager, L. F.; Polotsky, V. Y.; O’Donnell, C. P.; Cravo, S. L.; Lorenzi-Filho, G.; Machado, B. H. Am. J. Physiol. Heart Circ. Physiol. 309, H1101-H1111 (2015).

22) Engeli, S.; Bluher, M.; Jumpertz, R.; Wiesner, T.; Wirtz, H.; Bosse-Henck, A.; Stumvoll, M.; Batkai, S.; Pacher, P.; Harvey-White, J.; Kunos, G.; Jordan, J. J. Hypertens. 30, 2345-2351 (2012).

23) Artmann, A.; Petersen, G.; Hellgren, L. I.; Boberg, J.; Skonberg, C.; Nellemann, C.; Hansen, S. H.; Hansen, H. S. Biochim. Biophys. Acta 1781, 200-212 (2008).

24) Tilmann, A.; Müller, C.; Mahlberg, R.; Kunz, D.; Bes, F. J. Clin. Endocrinol. Metab. 89, 128-134 (2004).

25) Papandreou, C. J. Sleep Res. 22, 569-572 (2013).

26) Ferrarini, A.; Ruperez, F. J.; Erazo, M.; Martinez, M. P.; Villar-Alvarez, F.; Peces-Barba, G.; Gonzalez-Mangado, N.; Troncoso, M. F.; Ruiz-Cabello, J.; Barbas, C. Electrophoresis 34, 2873-2881 (2013).

27) Lebkuchen, A.; Carvalho, V. M.; Venturini, G.; Salgueiro, J. S.; Freitas, L. S.; Dellavance, A.; Martins, F. C.; Lorenzi-Filho, G.; Cardozo, K. H. M.; Drager, L. F. Sci. Rep. 8, 11270 (2018).

28) Davies, S. K.; Ang, J. E.; Revell, V. L.; Holmes, B.; Mann, A.; Robertson, F. P.; Cui, N.; Middleton, B.; Ackermann, K.; Kayser, M.; Thumser, A. E.; Raynaud, F. I.; Skene, D. J. Proc. Natl. Acad. Sci. USA 111, 1076110766 (2014).

29) Weljie, A. M.; Meerlo, P.; Goel, N.; Sengupta, A.; Kay- 
ser, M. S.; Abel, T.; Birnbaum, M. J.; Dinges, D. F.; Sehgal, A. Proc. Natl. Acad. Sci. USA 112, 2569-2574 (2015).

30） Xiao, Q.; Derkach, A.; Moore, S. C.; Zheng, W.; Shu, X. O.;
Gu, F.; Caporaso, N. E.; Sampson, J. N.; Matthews, C. E. Metabolomics 13, doi: 10.1007/s11306-017-1205-Z (2017). 